\title{
PENINGKATAN KAPASITAS PRODUKSI DAN PENDAPATAN USAHA PENGRAJIN KESET KAIN DI DESA CAGAKAGUNG KECAMATAN CERME KABUPATEN GRESIK
}

\author{
Rodhiyah $^{1}$, Andi Iswoyo ${ }^{2}$, Didik Daryanto ${ }^{3}$ \\ ${ }^{1,2,3}$ Universitas Wijaya Putra
}

rodiah@yahoo.co.id, andi@uwp.ac.id, didikdaryanto@uwp.ac.id

\begin{abstract}
Abstrak
Tujuan Program Pemberdayaan Masyarakat ini adalah untuk meningkatkan kapasitas dan kualitas produksi mitra. Permasalahan yang dihadapi mitra, antara lain; 1). Motif monoton pada bentuk oval dan bulat seperti produk dipasaran, perlu inovasi baru; 2). Peralatan produksi masih menggunakan mesin jahit manual dan jumlahnya kurang karena harus bergantian dengan anggota keluarga yang lain; 3). Tidak adanya quality control pasca produksi; 4). Pemasaran produk keset kain saat ini sebagian besar masih berdasarkan pesanan dan atau dititipkan di toko, belum ada upaya memasarkan lebih luas; Solusi yang ditawarkan antara lain; perlu pelatihan dan pendampingan desain produk dan keterampilan menjahit, pemasaran, dan pencatatan keuangan; pengadaan mesin jahit dan motor; pelatihan QC dan kesehatan kerja; Metode pelaksanaan yang digunakan adalah melalui; Pelatihan dan pendampingan, serta Pengadaan mesin jahit baru. Hasil pelaksanaan program antara lain; motif keset tidak hanya monoton, saat ini sudah lebih menarik dan variatif, mitra sudah mampu menjahit dengan baik, mitra sudah mencatat keuangan, mampu memasarkan produknya melalui media sosial dan produksi dan pendapatan meningkat sebesar $40 \%$.
\end{abstract}

Kata Kunci : Keset Kain, Pemberdayaan Masyarakat

PENDAHULUAN

Mitra dalam Program Pemberdayaan Masyarakat ini adalah Ibu Kasi Indrawati yang mengeluti usaha mikro pembuatan keset kain. Berlokasi di Dusun Agung Desa Cagakagung RT. 01 RW. 02 Kecamatan Cerme Kabupaten Gresik. Usaha ini dijalani mitra sejak tahun 2018. Setelah di PHK di perusahaan asal, mitra memutuskan untuk menggunakan uang pesangon yang didapat untuk memperbaiki rumah dan membuat usaha baru. Usaha yang saat ini dijalani adalah membuka toko kelontong dan pembuatan keset kain perca.
Usaha ini dipilih karena menurut mitra lebih mudah dan cepat menghasilkan. Pendapatan dari usaha pembuatan keset kain dirasakan mitra lebih menguntungkan dan hampir $60 \%$ pendapatan saat ini diperoleh dari usaha pembuatan keset kain (wawancara dengan mitra tgl. 10 April 2020). Sari, Haryono, \& Nugraheni, (2014) mengungkapkan hal senada bahwa kontribusi pendapatan ibu rumah tangga penjahit kain perca terhadap pendapatan total keluarga di Kecamatan Banyumas Kabupaten Pringsewu yang dikaji dari pendapatan kepala keluarga, jumlah tanggungan keluarga, tingkat pemenuhan kebutuhan pokok minimum keluarga,

Ekonomi, Sosial, dan Budaya

1089 
pendapatan ibu rumah tangga, kontribusi terhadap pendapatan total keluarga, serta kontribusi pendapatan ibu rumah tangga dapat mencapai $42,39 \%$. Mitra sangat berharap usaha pembuatan keset kain ini bisa berkembang dan menopang pendapatan keluarga karena saat ini, mitra merupakan tulang punggung keluarga setelah suaminya meninggal beberapa tahun yang lalu.

Keset kain perca sendiri merupakan produk yang lazim dibuat oleh ibu-ibu rumah tangga karena mudah pembuatannya dan murah karena menggunakan bahan limbah kain. Limbah kain didapat dari penjual yang mendapatkan limbah dari pabrik konfeksi di Gresik. Selain keset kain, mitra juga memproduksi produk yang sama yaitu tatakan dapur kain perca.

Berdasarkan hasil wawancara dengan mitra, berikut beberapa permasalahan yang dihadapi oleh mitra dalam menjalankan usahanya.

\section{Produksi}

Saat ini produksi keset kain perca belum banyak perkembangan. Dari sisi motif juga masih monoton dengan bentuk bulat atau oval. Hal ini dikarenakan minimnya pengetahuan dan kurangnya inovasi mitra. Tampilan produk masih kurang menarik, meskipun menurut mitra peminatnya cukup banyak dan mitra enggan menaikkan harga karena takut tidak laku. Produksi yang dihasilkan mitra dapat digambarkan sebagai berikut:

Tabel 1 Produksi Mitra

\begin{tabular}{|c|l|c|c|}
\hline No & Produk & $\begin{array}{c}\text { Kapasitas } \\
\text { Produksi } \\
\text { per hari) }\end{array}$ & $\begin{array}{c}\text { Permintaan } \\
\text { Pasar (per hari) }\end{array}$ \\
\hline 1 & $\begin{array}{l}\text { Keset Kain } \\
\text { Oval }\end{array}$ & 4 buah & 20 buah \\
\hline 2 & $\begin{array}{l}\text { Keset Kain } \\
\text { Bulat }\end{array}$ & 3 buah & 20 buah \\
\hline 3 & Tatakan dapur & 6 buah & 10 buah \\
\hline
\end{tabular}

Dari tabel diatas, permintaan pasar masih cukup besar, selain karena murah permintaan pasar juga karena kualitas keset kain ini lebih baik dan lebih awet. Besarnya permintaan pasar tersebut masih belum bisa dipenuhi oleh mitra karena kapasitas produksi dan tenaga yang kurang. Permintaan pasar saat ini disikapi mitra dengan sistem pesan antar.

Peralatan yang digunakan mitra saat ini hanya menggunakan mesin jahit manual yang digerakkan dengan kaki, belum menggunaan motor. Hal ini karena mitra belum memiliki motor mesin jahit dan masih kurang trampil dalam mengoperasikannya. Proses produksi keset kain perca dimulai dari pemilahan kain berdasarkan jenis dan warnanya, kemudian dipotong sesuai ukuran, kemudian pembuatan pola kain segitiga dan proses berikutnya adalah penjahitan. Proses yang yang membutuhkan lama adalah pada saat membuat pola segitiga, proses ini dimulai dengan pemotongan kain perca kemudian melipat dan memasukkan pada jarum sehingga pola

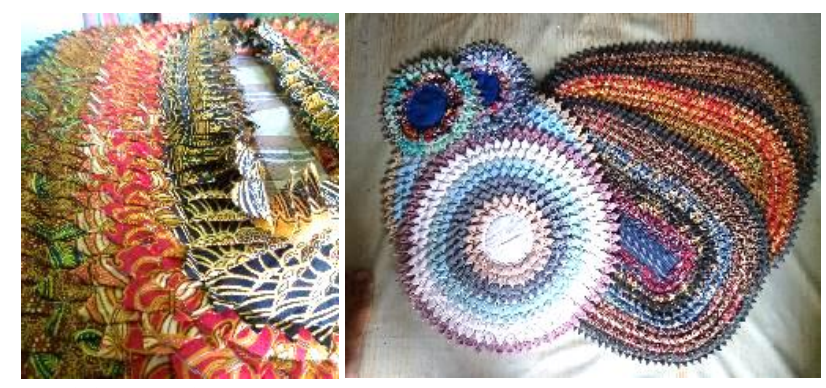

segitiga terkumpul pada benang.

Gambar 1 Produk setengah jadi dan produk jadi

Mitra bisa saja membeli bahan setengah jadi namun harganya lebih mahal sehingga mengurangi pendapatan.

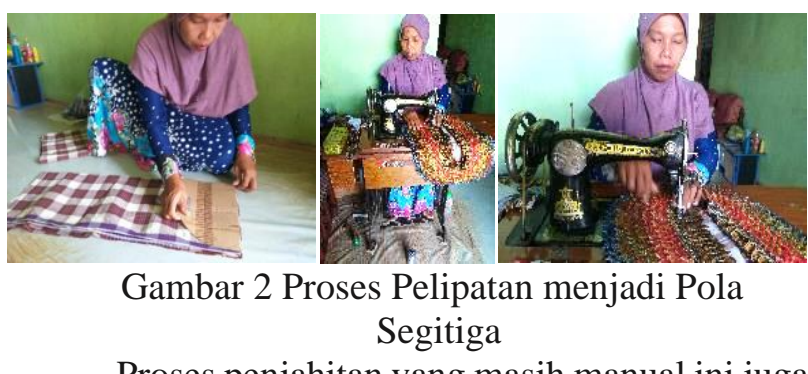

Proses penjahitan yang masih manual ini juga menyebabkan mitra sering mengeluh pegal di kaki dan pungung, kursi jahit juga kurang ergonomis dan tanpa sandaran sehingga kurang nyaman.

Berdasarkan penelitian Zuraida (2012) menyatakan bahwa rasa nyeri dan tidak nyaman penjahit keset limbah disebabkan oleh pekerja berada dalam postur kerja yang beresiko menyebabkan cedera akibat salah satu postur tubuh yang tidak baik. Sehingga peneliti menyarankan pekerja untuk mengurangi keluhan tersebut dengan kursi dengan penyangga bantalan punggung dan pantat. Bahan baku kain perca didapatkan mitra dari pengepul limbah kain dari pabrik di Gresik. Berdasarkan 
informasi dari mitra, saat ini hanya ada 1 pengepul kain limba di Gresik. Minimnya pengepul/supplier

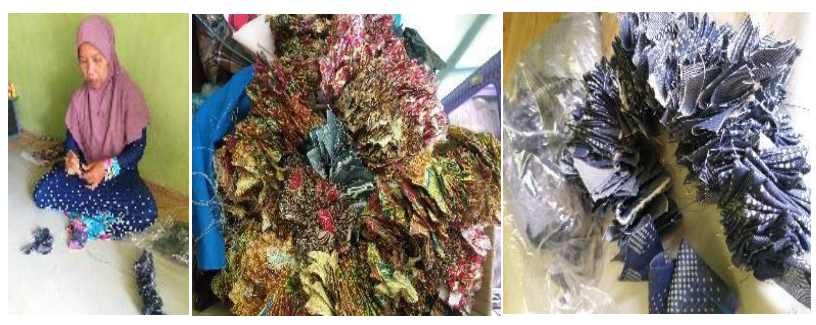

bahan baku ini menyebabkan, supplier bisa memainkan harga bahan dengan seenaknya. Belum ada upaya dari mitra untuk mencari supplier lain dan atau mengambil daru baju bekas.

Gambar 3 Proses Pembuatan Dasar Keset Kain dan Proses Penjahitan

Permasalahan lainnya adalah mitra belum memiliki inovasi dalam hal desain. Sebagaimana dalam gambar 1 diatas, bentuk dasar produk hanya oval dan lingkaran dan motif yang ada hanya terbatas pada pola mengikuti bentuk dasarnya, sehingga tampilan kurang menarik. Mitra sudah mampu memilah-milah corak dan warna kain sehingga seharusnya sudah bisa membentuk pola dasar atau motif yang lebih menarik.

Mitra tidak melakukan quality control pada produk yang dihasilkan, masih banyak proses penjahitan yang kurang sempurna, namun menurut mitra itu masih bisa diterima oleh pelanggan dan belum ada komplain. Menurut tim pelaksana hal ini kurang tepat karena produk yang baik akan sangat berpengaruh pada kepuasan pelanggan, selain itu hal tersebut juga dikarenakan kurang terampilnya mitra dalam menjahit dan karena penggunaan mesin jahit manual.

\section{Manajemen}

Pemasaran produk keset kain saat ini sebagian besar masih berdasarkan pesanan, ketika tidak ada pesanan oleh mitra produk keset kain ini dijual kepasar dimana selalu ada toko yang bersedia menerima meskipun dengan pembayaran setelah barang terjual. Selama proses penjualan, produk tidak dikemas, menurut mitra hal ini dikarenakan produknya awet dan tidak mudah rusak sehingga tidak perlu dikemas. Selain itu produk juga belum diberi label yang menunjukkan keset kain tersebut adalah produk mitra.

Proses distribusi produk saat ini dilakukan sendiri oleh mitra atau meminta kepada anggota keluarga yang lain untuk membantu mengirimkan kepada pembeli dan atau pembeli datang sendiri ketempat produksi di rumah mitra.

Tenaga kerja yang membantu proses produksi adalah anggota keluarga yaitu adik mitra, hal itu dikerjakan secara bergantian karena mesin jahit yang dimiliki hanya satu. Sedangkan untuk pengiriman dibantu oleh anak mitra. Menurut mitra saat ini belum membutuhkan tenaga tambahan dikarenakan masih bisa menyelesaikan pesanan meskipun butuh waktu dan kadang harus dikerjakan lembur.

Masalah lainnya yang dihadapi mitra adalah tidak ada pencatatan keuangan dan perencanaan produksi. Menurut mitra, hal itu tidak dilakukan karena tidak ada waktu untuk mengerjakan itu dan perencanaan produksi juga tidak banyak hanya berdasarkan pesanan dan saat ini tidak mampu untuk membuat persediaan barang jadi. Dalam hal penetapan harga jual, mitra masih belum bisa menghitung dengan tepat, dimana harga jual ditentukan berdasarkan harga pasar, karena mitra takut produknya tidak laku dipasaran. Berikut harga pokok produksi dan harga pokok penjualan produk mitra:

Tabel 2 Harga Pokok Produksi dan Harga Pokok Penjualan

\begin{tabular}{|c|l|c|c|}
\hline No. & \multicolumn{1}{|c|}{ Produk } & $\begin{array}{c}\text { Harga } \\
\text { Pokok } \\
\text { Produksi }\end{array}$ & $\begin{array}{c}\text { Harga } \\
\text { Pokok } \\
\text { Penjualan }\end{array}$ \\
\hline 1 & Keset Oval & Rp. 4.500,- & Rp. 6.000,- \\
\hline 2 & Keset Bulat & Rp. 3.500,- & Rp. 5.000,- \\
\hline 3 & Tatakan Dapur & Rp. 1.500,- & Rp. 2.500,- \\
\hline
\end{tabular}

Dari sisi kesehatan produksi, mitra belum cukup baik dalam menerapkan kesehatan kerja, diantaranya adalah tidak memakai masker dan celemek. Pemakaian masker seharusnya wajib bagi pekerja tekstil karena debu dari benang/kain sangat berbahaya bagi kesehatan. Selain itu, tempat duduk saat menjahit menggunakan kursi tanpa sandaran sehingga sering mengeluh sakit punggung dan pinggang karena lama duduk tanpa bantalan dan kursi terlalu rendah.

\section{Permasalahan Mitra}

Mengacu kepada butir Analisis Situasi diatas, tim pelaksana memisahkan menjadi 2 
permasalahan utama yaitu di bidang produksi dan manajemen. ermasalahan dalam produksi adalah ketidakmampuan mitra untuk meningkatkan kapasitas dan mutu produksi, sesuai dengan permintaan pasar yang meningkat karena proses produksi menggunakan cara manual yang tidak efisien. Sedangkan permasalahan manajemen diklasifikasi menjadi permasalahan pemasaran, manajemen, administrasi keuangan, serta manajemen mutu dan kesehatan. Permasalahan yang dihadapi mitra dan diprogramkan untuk diselesaikan dalam kegiatan ini, antara lain;

1. Desain Produk, motif monoton pada bentuk oval dan bulat seperti produk dipasaran, perlu inovasi baru;

2. Peralatan, Peralatan produksi masih menggunakan mesin jahit manual dan jumlahnya kurang karena harus bergantian dengan anggota keluarga yang lain

3. Mitra sering mengeluh sakit dipunggung dan pinggang karena terlalu lama menjahit, hal ini karena kursi kurang ergonomis dan tanpa sandaran
4. Bahan Baku, pengadaan bahan baku terkendala minimnya pemasok Pelatihan pemanfaatan kain perca dari limbah baju dan motif berbeda sehingga mengurangi limbah ulang

5. Quality Control, tidak adanya quality control pasca produksi;

6. Pemasaran, pemasaran produk keset kain saat ini sebagian besar masih berdasarkan pesanan dan atau dititipkan di toko, belum ada upaya memasarkan lebih luas;

7. Keuangan, tidak ada pencatatan keuangan dan perencanaan produksi dan penetapan harga jual belum dihitung dengan tepat, dimana harga jual ditentukan berdasarkan harga pasar; dan

8. Kesehatan Kerja, mitra belum cukup baik dalam menerapkan kesehatan kerja, diantaranya adalah tidak memakai masker dan celemek

\section{Solusi yang Ditawarkan}

Berdasarkan permasalahan diatas dan berdasarkan diskusi dengan mitra, berikut solusi dan target luaran yang disepakati untuk menyelesaikan permasalahan yang dihadapi mitra, sebagai berikut:

Tabel 4 Solusi dan Target Luaran 


\section{METODE}

Dalam rangka melaksanakan solusi dan mencapai target luaran diatas, berikut metode pelaksanaan kegiatan yang menjelaskan tahapan atau langkah-langkah dalam melaksanakan solusi yang ditawarkan untuk mengatasi permasalahan sebagai berikut:

1. Berkoordinasi dengan mitra, supplier dan pihak terkait dalam program ini

2. Melaksanakan pelatihan dan pendampingan, yaitu:

a. Desain produk dan keterampilan menjahit

b. Quality Control dan Kesehatan Kerja

c. Pencatatan keuangan dan penetapan HPP/HPJ, dan

d. Pemasaran offline dan online

3. Pengadaan mesin jahit baru dan motor jahit

4. Pengadaan kursi jahit yang ergonomis

5. Pendampingan pasca program
Monitoring dan evaluasi pelaksanaan program

\section{HASIL DAN PEMBAHASAN}

Kegiatan dalam Program Pemberdayaan Masyarakat ini diarahkan terutama pada peningkatan kapasitas produksi dan penjualan mitra. Kondisi awal saat ini, mitra masih belum bisa memenuhi permintaan meskipun hanya melakukan produksi hanya saat ada pesanan.

Kegiatan awal yang dilakukan oleh tim peneliti adalah berkoordinasi dengan mitra tentang permasalahan prioritas yang akan diselesaikan, menyepakati jadwal kegiatan dan pengadaan barang yang dibutuhkan mitra. Berikut kegiatan yang telah dilaksanakan untuk menyelesaikan permasalahan mitra.

\begin{tabular}{|c|c|c|c|}
\hline No. & Permasalahan Mitra & Solusi & Target Luaran \\
\hline 1 & $\begin{array}{l}\text { Motif monoton pada bentuk oval dan } \\
\text { bulat seperti produk dipasaran, perlu } \\
\text { inovasi baru }\end{array}$ & $\begin{array}{l}\text { Perlu pelatihan dan pendampingan } \\
\text { desain produk dan keterampilan } \\
\text { menjahit }\end{array}$ & \multirow[t]{2}{*}{$\begin{array}{l}\text { Terlaksana } 2 \text { kali pelatihan dan } \\
\text { pendampingan desain produk } \\
\text { dan keterampilan menjahit }\end{array}$} \\
\hline 2 & $\begin{array}{l}\text { Mitra belum cukup baik dalam } \\
\text { menerapkan kesehatan kerja, diantaranya } \\
\text { adalah tidak memakai masker dan } \\
\text { celemek. }\end{array}$ & $\begin{array}{l}\text { Perlu pelatihan dan pendampingan } \\
\text { desain produk dan keterampilan } \\
\text { menjahit }\end{array}$ & \\
\hline 3 & $\begin{array}{l}\text { Peralatan produksi masih menggunakan } \\
\text { mesin jahit manual dan jumlahnya kurang } \\
\text { karena harus bergantian dengan anggota } \\
\text { keluarga yang lain }\end{array}$ & Pengadaan mesin jahit dan motor & $\begin{array}{l}\text { Tersedia } 1 \text { unit mesin jahit baru } \\
\text { dan tersedia } 1 \text { unit motor jahit }\end{array}$ \\
\hline 4 & $\begin{array}{l}\text { Mitra sering mengeluh sakit dipunggung } \\
\text { dan pinggang karena terlalu lama } \\
\text { menjahit, hal ini karena kursi kurang } \\
\text { ergonomis dan tanpa sandaran }\end{array}$ & Pengadaan kursi jahit & $\begin{array}{l}\text { Tersedia } 2 \text { kursi jahit yang } \\
\text { ergonomis }\end{array}$ \\
\hline 5 & $\begin{array}{l}\text { Tidak adanya quality control pasca } \\
\text { produksi }\end{array}$ & $\begin{array}{l}\text { Pelatihan dan pendampingan QC } \\
\text { dan Kesehatan Kerja }\end{array}$ & $\begin{array}{l}\text { Terlaksana } 1 \text { kali pelatihan dan } \\
\text { pendampingan QC dan } \\
\text { Kesehatan Kerja }\end{array}$ \\
\hline 6 & $\begin{array}{l}\text { Pemasaran produk keset kain saat ini } \\
\text { sebagian besar masih berdasarkan pesanan } \\
\text { dan atau dititipkan di toko, belum ada } \\
\text { upaya memasarkan lebih luas }\end{array}$ & $\begin{array}{l}\text { Pelatihan dan pendampingan } \\
\text { pemasaran }\end{array}$ & $\begin{array}{l}\text { Terlaksana } 1 \text { kali pelatihan dan } \\
\text { pendampingan pemasaran }\end{array}$ \\
\hline 7 & $\begin{array}{l}\text { Tidak ada pencatatan keuangan dan } \\
\text { perencanaan produksi. }\end{array}$ & $\begin{array}{l}\text { Pelatihan dan pendampingan } \\
\text { pencatatan keuangan dan penetapan } \\
\text { HPP/HPJ }\end{array}$ & $\begin{array}{l}\text { Terlaksana } 1 \text { kali pelatihan dan } \\
3 \text { kali pendampingan pencatatan } \\
\text { keuangan dan penetapan } \\
\text { HPP/HPJ }\end{array}$ \\
\hline
\end{tabular}

Ekonomi, Sosial, dan Budaya 


\section{Pelatihan dan pendampingan desain produk dan keterampilan menjahit}

Kondisi awal mitra sudah bisa menjahit namun masih sebatas desain dasar saja, belum bisa membuat pola yang bagus dan belum bisa menyelesaikan sendiri jika ada kendala dalam menjahit, seperti benang loncat, jahitan masih kasar, kurang rapi, dan lain-lain. Selain itu pola/desain yang dibuat mitra masih sederhana yaitu terbatas pada bentuk bulat atau oval, tidak ada pola tertentu.

Program ini memberikan pelatihan membuat desain keset kain yang unik dan menarik, sehingga diminati konsumen. Tim pengusul membuat pola diatas kertas dan memberikan kepada mitra untuk belajar membuat pola dan pemilihan warna kain untuk kemudian diaplikasikan pada proses penjahitan.

Gambar 4 Beberapa desain keset kain pada kertas

$$
\text { kerja }
$$

Pelatihan berikutnya adalah memberikan pelatihan menjahit dengan pola melingkar dan dengan kain lipat/tebal dan pola penutup ditengah bahan. Kegiatan ini dilakukan selama 3 (tiga) kali pelatihan, mengingat kendalam mitra dalam memahami materi pelatihan selain itu juga karena mesin jahit yang digunakan sering rusak.
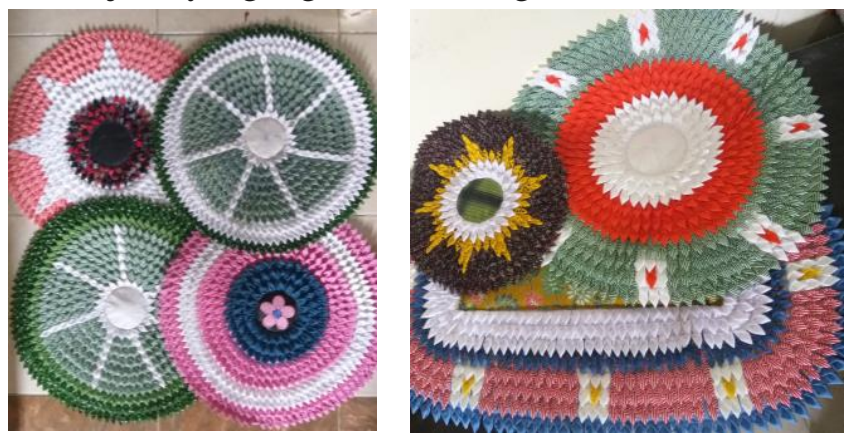

Gambar 5 Produk jadi

Setelah pengadaan mesin jahit bermotor, diadakan pelatihan pengoperasiannya dan mitra juga diajarkan cara perawatan dan maintenance ringan.

\section{Pengadaan Peralatan Kerja}

Salah satu yang menjadi kendala utama dalam proses membuat kain adalah mesin jahit yang dimiliki mitra sering rusak, masih manual dan tidak bisa digunakan untuk menjahit pola melingkar dengan ketebalan kain keset. Sebagaimana yang telah diprogramkan, tim pelaksana memberikan 1 (satu) unit mesin jahit dengan motor listrik. Pengadaan mesin jahit ini dapat mempercepat produksi kain hingga $40 \%$. Berikut perbandingan kapasitas produksi per minggu sebelum dan sesudah pengadaan mesin jahit:

Tabel 5 Kapasitas produksi pasca pengadaan mesin

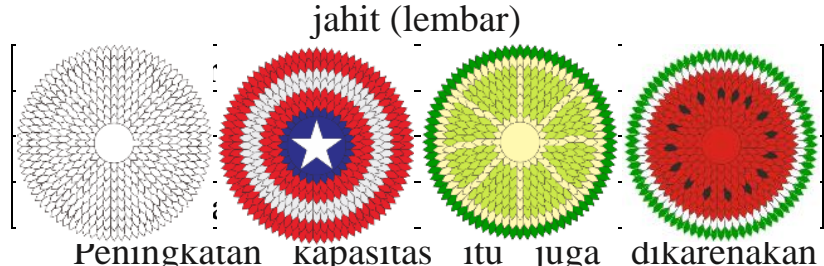
waktu perbaikan kerusakan ringan pada mesin jahit lama menjadi berkurang, karena hampir tidak ada kendala/kerusakan ketika menggunakan mesin jahit baru dan menggunakan motor sehingga produksi lebih cepat.

Kendala yang dihadapi sampai dengan selesainya program ini adalah mitra masih belum bisa menyesuaikan dengan mesin jahit baru, sehingga masih perlu pendampingan secara berkelanjutan.

\section{Pelatihan dan pendampingan QC dan Kesehatan Kerja}

Pelatihan ini diberikan dengan memberikan pemahaman tentang pentingnya kerapian dalam produksi sehingga konsumen bisa puas terhadap produknya. Pengawasan kualitas ini dilakukan pada pemotongan sisa benang jahitan, kain yang lepas dari jahitan, dan kerapian.

Selain itu juga diberikan pemahaman tentang pentingnya penggunaan alat kesehatan selama Ekonomi, Sosial, dan Budaya

1094 
produksi, misalkan penggunaan masker, celemek dan membersihkan lingkungan kerja sebelum dan setelah produksi.

Dampak dari pelatihan ini mitra lebih disiplin dalam berproduksi dan selama pendampingan mitra sudah terbiasa dengan pila kerja bersih dan sehat.

\section{Pelatihan dan pendampingan pemasaran}

Pelatihan ini diberikan agar penjualan produk keset kain makin luas dan dikenal masyarakat, bentuk pelatihan ini dilakukan dengan memberikan tugas kepada mitra setiap minggu harus bisa mendapatkan 1 (satu) orang pelanggan baru dan memastikan pelanggan lama bisa order kembali. Selain itu juga dibuatkan akun di Instagram dan marketplace (Tokopedia dan BukaLapak).

Dampak pelatihan ini masih belum bisa dirasakan manfaatnya, namun menurut mitra sudah ada beberapa pelanggan baru yang bertanya tentang produk sehingga dapat dikatakan produk mitra sudah dikenal di beberapa daerah.

\section{Pelatihan dan pendampingan pencatatan keuangan dan penetapan HPP/HPJ}

Pelatihan ini ditujukan agar mitra mampu menghitung tingkat laba/rugi produksi. Tim pelaksana berusaha untuk membuat materi yang sangat sederhana agar materi yang diberikan bisa dipahami oleh mitra. Materi yang diberikan antara lain; menghitung harga pokok penjualan, pencatatan semua transaksi yang dilakukan, pemisahan keuangan usaha dan keuangan rumah tangga serta menghitung laba/rugi.

Setelah pelatihan, juga diberikan pendampingan untuk memastikan mitra melakukan semua yang diberikan pada saat pelatihan. Dampak pelatihan ini, mitra sudah bisa menghitung harga pokok produksi dimana mitra bersedia untuk menaikkan harga jualnya dikarenakan kualitas produknya bagus dan bahan yang digunakan juga bagus, selain itu, mitra juga sudah disiplin mencatat transaksi usaha, namun masih kesulitan untuk menghitung laba/rugi karena masih bercampur dengan keuangan rumah tangga.

\section{KESIMPULAN}

Berdasarkan program pemberdayaan masyarakat yang telah dilaksanakan, dampaknya sangat dirasakan manfaatnya oleh mitra, diantaranya ada kenaikan kapasitas produksi sebesar $40 \%$ dan juga diikuti oleh perbaikan kualitas produk. Mitra juga sudah mampu melakukan pengawasan kualitas dan menggunakan alat pelindung diri saat produksi, ada penambahan peralatan berupa mesin jahit baru, ada perluasan potensi pasar penjualan meskipun belum berdampak pada penjualan.

Mitra sudah mampu menghitung harga pokok produksi dan harga pokok penjualan, sudah disiplin mencatat transaksi harian, namun masih perlu pendampingan untuk dapat menghitung laba/rugi dan mengatur keuangan usaha.

\section{UCAPAN TERIMAKASIH}

Ucapan terimakasih disampaikan kepada Universitas Wijaya Putra dan Lembaga Penelitian dan Pengabdian Kepada Masyarakat Universitas Wijaya Putra yang telah memberikan pendanaan dan dukungan dalam pelaksanaan program pemberdayan masyarakat ini. Ucapan terima kasih juga kami sampaikan kepada Mitra PPM dan Pemerintah Desa Cagakagung Kecamatan Cerme Kabupaten Gresik.

\section{REFERENSI}

Sari, R. S., Haryono, E., \& Nugraheni, I. L. (2014). Kontribusi Pendapatan Ibu Rumah Tangga Penjahit Kain Perca Terhadap Pendapatan Total Keluarga. Jurnal Penelitian Geografi, 2(5), 2-10. https://doi.org/10.1038/132817a0

Zuraida, R. (2012). Analisis Penyebab Nyeri dan Ketidaknyamanan dalam Bekerja pada Pengrajin Keset Kain Limbah-Pringapus Semarang. ComTech: Computer, Mathematics and Engineering Applications, 3(1), 573-583. https://doi.org/10.21512/comtech.v3i1.2456 